\title{
The complicated life of a physician-soldier: Medical readiness training exercises \& the problem of dual loyalties
}

\author{
Sheena M. Eagan Chamberlin \\ Institute for the Medical Humanities, University of Texas Medical Branch, Galveston, USA \\ Email: Sechamberlin@me.com
}

Received 14 August 2013; revised 6 September 2013; accepted 12 September 2013

Copyright (C 2013 Sheena M. Eagan Chamberlin. This is an open access article distributed under the Creative Commons Attribution License, which permits unrestricted use, distribution, and reproduction in any medium, provided the original work is properly cited.

\begin{abstract}
While physicians are generally understood as owing moral obligation to the health and well being of their individual patients, military health professionals can face ethical tensions between responsibilities to individual patients and responsibilities to the military mission. The conflicting obligations of the two roles held by the physician-soldier are often referred to as the problem of dual loyalties and have long been a topic of debate. This paper seeks to enrich the dualloyalties debate by examining the embedded case study of medical civilian assistance programs. These programs represent the use of medicine within the military for strategic goals. Thus, a physician is expected to meet his obligation to his role as a soldier while also practicing medicine. These programs involve obligations inherent in both roles of the physician-soldier and thusly they serve as excellent exemplars for the problem of dual loyalties at an institutional level. This paper focuses on Medical Readiness Training Exercises (MEDRETEs). These programs are short-term, generally taking place in low-income nations in order to accomplish strategic goals including training opportunities for military medical professionals that are not possible on the home front. This form of temporary program raises ethical concerns regarding the exploitation of vulnerable populations and the value of what is termed "parachute medicine". The short-term nature of these interventions makes long-term treatment and follow-up impossible, begging the question as to whether this peak and trough approach to foreign civilian aid is of any use. Physicians are generally understood as having obligations towards the well being of the patient, which these programs do not necessarily prioritize. Rather, the programmatic intent is military, with political and strategic aims of furthering international relations, increasing US military global presence and
\end{abstract}

providing austere and tropical training opportunities for military healthcare providers. This can be morally problematic for the physician-soldier.

Keywords: Military Medicine; Dual Loyalty; Medical Ethics; History of Medicine; Military History; Military Ethics; MEDRETEs; Civic Action

\section{INTRODUCTION}

Military physicians are simultaneously members of two professions. Identifying as both soldiers and physicians can occasionally create moral dilemmas that are unique to military medicine. This complicated moral experience has been called the "problem of dual-loyalties" or sometimes "mixed agency", and has been understood as a fundamental issue in military medical ethics. These military medical professionals have historically found themselves confronted with situations where military protocol, orders or strategy require them to act or behave in a way that is contrary to norms of civilian medical ethics, occasionally valuing the mission over the individual patient. This creates a morally complicated space in which the military physician must practice. Critical reflection and inquiry are needed to understand this uniquely complicated combination of professions and the moral dilemmas faced by these practitioners.

This paper will explore the problems faced by physician-soldiers in light of their dual-loyalty. Analysis will use a case study design to examine the dual-loyalties issue on an institutional level, offering an in-depth description of the dual-loyalties problem as experienced by military physicians as well as a broader understanding of the medico-military intersection, where medicine and the military strive, through a single program, for seemingly disparate goals. The case study focuses on medical civilian assistance programs, which include all formal, informal and ad hoc missions during which uniformed per- 
sonnel provided medical care to civilian populations as part of their military duties.

\section{MEDICAL CIVILIAN ASSISTANCE \& THE PROBLEM OF DUAL-LOYALTY}

The security policy has shifted towards stability operations that often prioritize medical operations such as this. Stability operations, including Humanitarian and civic assistance has become an important part of the military mission. National policy has emphasized and prioritized these types of missions within the American armed forces. According to Department of Defense (DOD) Instruction 3000.05 Military stability operations (MSOs) are a "core US military mission", that "shall be given priority comparable to combat operations..." [1] This shift signifies formal recognition of America's role on the international level, and new technique in achieving American military goals.

The military institutionalizes the dual-loyalty problem with missions such as medical civilian assistance programs by combining both military and medical goals into a single program or mission. Now that these programs are being prioritized at the same level as combat missions they must be studied. This critical reflection and analysis is the key to the formation of institutional knowledge. However, little analysis has taken place. In fact, there is little institutional memory and sparse record keeping when it comes to key medical civilian assistance programs, and even these records do not paint a full picture of these missions. This paper introduces oral history data into this discussion. The stories shared by these military physicians provide valuable insight into a uniquely complicated profession. This paper will share those stories providing in-depth historico-ethical analysis of these programs, as well as the problem of dual loyalties.

American military medical professionals have been providing medical care to civilian populations since the beginning of formalized Army medicine. In fact, evidence of civilian medical assistance programs dates back to the Revolutionary War when the American Army first organized [2]. During that time, military medical personnel often provided care to civilians who lived in the vicinity of Army camps and bases. This care was provided out of a motivation to better or maintain the health of soldiers by improving hygiene and reducing epidemic disease, rather than to improve the health of the civilian population. This meant that civilian assistance had a decidedly strategic purpose; improved civilian health meant a reduction in epidemic disease, and thus a healthy and disease-free army, which meant a higher likelihood of mission success. The use of medicine to accomplish strategic goals would go on to form the foundation for medical civilian assistance programs, as the military recog- nized a new tool in its strategic arsenal. Despite the long history of medical civilian assistance programs, these programs were not officially formalized and emphasized by the American military until much later.

After the Second World War, the US began to shift away from the isolationist tendencies that had shaped its previous foreign policy [3]. In the period between 19491960 US foreign policy began to emphasize assistance to foreign nations that were sympathetic to western democracy and opposed to communism. This period was followed by an era of US policy that shifted toward a balance of military force and humanitarian assistance [3]. In the post-Vietnam era, US national policy took interest in South and Central America. Official history notes that the US recognized a low-intensity threat in Latin America caused by regional violence and destabilization [4]. Journalist Juan Gonzalez has argued that US economic and military interests played a role in destabilizing Latin America, creating a relationship of migration and dependence with the United States [5]. In response to this instability, the US Southern Command (SOUTHCOM) command surgeon's staff developed The Regional Medical Strategy. This strategy sought to use medical initiatives in conjunction with military assets to assist Latin American host governments address the health care needs of their country. The hope was that in assisting the host government augment host nation medical capabilities, the US would successfully preempt the possibility that the lack of health care would become an insurgent issue [4]. The two countries of specific focus were El Salvador and Honduras [6].

The development, stabilization, and security assistance missions were in line with both US national policy and DOD directives. DOD directive 5132.3 established military policy for security and civic assistance missions stating, "security assistance is an integral part of the DOD mission" [7]. In fact, many senior military officials believed that the Army should be involved with Latin and South American countries, as a partner for development [8]. The US was also interested in increasing its sphere of influence to encompass South America due to the area's rich natural resources, such as oil [9].

These missions involved the use of non-violent military means, which is generally understood to mean "the provision of training, equipment, personnel or other programs utilizing military resources” [10]. Before stabilization and development assistance became a focus of US foreign policy, nonviolent military means had referred to the ramping up and scaling back of support forces before and after hostilities. However, as the US became engaged in this type of nation development and assistance, it recognized that the support forces (including medical) could be used beyond simply augmenting combat power. These support forces could be utilized as a separate and distinct 
element of power [10]. This recognition was due partly to the perceived success of Medical Civic Action Programs (MEDCAPs) and other medical civilian assistance programs during the Vietnam War. Thus, medical civic action became a prominent component of stabilization and development efforts during the later part of the twentieth century in Latin, Central and South America. The use of medicine in Latin America was recognized as "the least controversial, most cost effective and politically acceptable" means of furthering American military interests [11]. Still, much like the programs of Vietnam that inspired them, published commentators critiqued these programs as small, limited and tending to "concentrate on high impact, short range projects” [12]. Similar to their predecessor programs in Vietnam, the short term and temporary nature of these missions lent themselves to contextual challenges regarding medical goals, such as limited patient care, education and follow-up.

The Central and Latin American programs began in Honduras, a country that would go on to receive a great deal of medical civilian assistance from all branches of the US military. COL Zajtchuk, part of Joint Task Force Bravo (JTF-Bravo) amended the MEDCAP model from Vietnam to create the modern MEDRETE. JTF-Bravo represented US Southern Command in Honduras, working with Host-Nation governments in their area of responsibility to organize various comprehensive humanitarian assistance programs, as a part of the stabilization and development missions that were now a priority within US national policy [13]. Zajtchuk held the belief that humanitarian and civic assistance activities or HCAs had "the potential of becoming the greatest promoter of developing positive US policy in Central America" [14]. He also believed that these programs would be a good way for him to occupy the time of his staff, improving troop morale and preventing boredom [14].

One of his largest and most successful programs was the MEDCAP. These MEDCAPs were modeled after those conducted in Vietnam and said to be the "mirrorimage of their Vietnam-counterparts" [15]. However, there were some substantial changes between the MEDCAPs in Vietnam and those being carried out in Honduras. According to Zajtchuk, the intention behind this program was "to take advantage of a unique opportunity and provide US physicians, nurses, administrators, medics and support personnel field training that are unavailable elsewhere" [15].

In Vietnam, the main focus had been psychological warfare; in Honduras the MEDCAP was now a training mission with the specific purpose of enhancing a military medical professional's ability to practice medicine in austere conditions [16]. As it no longer prioritized the same goals as the MEDCAP, this reorientation led to a change in name. The program began operating under the name Medical Readiness Training Exercise or MEDRETE [16]. The title better reflected the main purpose of the program: the training of military medical personnel in environments that could not be accurately replicated in the US. Low-income nations and the isolated rural populations presented diseases and illness that physicians, nurses and medics rarely saw in the US. Beyond that, the temporary clinical setting of the impoverished rural village was far from the western hospital in which they trained and worked. MEDRETEs provided many training opportunities that the military saw as advantageous for military readiness and mission success.

\section{MEDICAL READINESS TRAINING EXERCISES-MEDRETES}

MEDRETEs have involved many different types of medical care and a wide variety of medical specialties. The most common is the general multi-medical specialties MEDRETE. This two-week MEDRETE provides primary care to remote, often rural, locations in lowincome nations in conjunction with the host nation's government and ministry of health [17]. Generally, this includes immunizations, basic clinical care and dental activities [17]. Some MEDRETEs also prioritize preventive medicine and civilian health education [17]. More specialized MEDRETEs include those involving specialty surgical teams performing cleft lip and palate repair, hand reconstruction, plastic surgery on burn patients, orthopedics and urology [17]. DENTRETEs also represent a popular and common subspecialty of the MEDRETE program, during which dentists perform tooth extractions, tend to dental emergencies, apply fluoride and provide oral hygiene education [17].

\subsection{MEDRETE—Programmatic Intent}

Although there was little doctrine to inform the behaviour of individual soldiers engaged in these missions, the official intent is clearly documented. Stabilization and development missions, such as the MEDRETE, were understood to fall under the umbrella of military civic action or MCA. According to Field Manual 41 - 10, MCA projects are:

... Designed and intended to win support of the local population for government objectives and for the military. Properly planned and executed MCA projects result in popular support. MCA employs predominately indigenous military forces as labor and is planned as short-term projects [18].

This definition, with a decidedly strategic purpose, serves to distinguish MCA from the civic action done by the United States Agency for International Development or USAID, which includes forces of humanitarian assis- 
tance such as disaster relief. DOD Instruction 2205.02 provides greater understanding of the military conception of "Humanitarian and Civic Assistance Activities" or HCAs [19]. This DOD instruction directs US Armed Forces personnel to

Participate in HCA activities to create strategic, operational, and/or tactical effects that support Combatant Commander objectives in theatre security cooperation or designated contingency plans while concurrently reinforcing skills required for the operational readiness of the forces executing the HCA mission... [19].

This doctrine is reiterated in an earlier in- struction, 2205.3: "Implementing Procedures for the Humanitarian and Civic Assistance (HCA) Program", which states "HCA activities shall promote the foreign policy and national security interests of the United States and the Specific operational readiness skills of the US Armed Forces who participate in the activities" [20]. The strategic focus of these missions is also apparent in read- ing the official website of Joint Task Force Bravo, who has been and remains responsible for the majority of Army MEDRETES in Honduras and other SOUTHCOM countries. According to their site,

There are several mission objectives to MEDRETES, to include providing US military personnel training in delivery of medical care in austere conditions, promoting diplomatic relations between the US and host nations in Central America, and providing humanitarian and civic assistance via a long-term proactive program. These exercises bring together key members of the US and foreign militaries, US Embassy Country Teams, US Non-Governmental Organizations (NGO's), Host Nation (HN) government agencies and indigenous civilian organizations [17].

This military doctrine is clearly strategic. The missions are not humanitarian in nature but rather seek to fulfill military goals, and emphasize strategic aims including training and international diplomacy. Medical civic action programs, which were reoriented and renamed medical readiness training exercises during this period, fell under the umbrella of MCA and HCA doctrine. Thus, their primary motivation is military not medical.

The strategic purpose of these programs was not lost on participants. In a letter to the editor that was published in the journal Military Medicine, one author who had experience developing these programs wrote, "the primary missions of MEDRETES has never been to resolve health problems of the people in the host-nation, but to train our military service elements to be ready for war"
[21]. Importantly the author also described the many benefits that these programs can have for the host nation civilian populations.

As training missions, MEDRETES have been invaluable and worth much more in skill learning, time and money than the simulated domestic (US) training of our active and reserve components. As benefits for foreign host-nation recipients, MEDRETEs serve a limited but good, useful service, including some preventive medicine teaching as part of care [21].

Participants and commentators recognized the potential benefits and the potential pitfalls of these programs, almost from their first implementation in the post-Vietnam era. These programs offered an inexpensive and excellent opportunity for public relations and training [22]. Although they were recognized as a significant and powerful policy tool if they were conducted properly, many believed that irresponsibly conducted medical civilian assistance could be counterproductive [23]. They feared that if the Vietnam MEDCAP style was perpetuated, where strategic concerns subverted medical goals leading to the provision of subpar medical care, the military interests could suffer from the distrust that this could engender.

\subsection{The Promise \& Pitfalls of MEDRETEs}

The recognition of both the potential positive benefits and negative consequences of these programs is prominent in the written and interview discussions with participants who reflect on their own experiences on specific missions. Honduras was the recipient of a substantial amount of medical civilian assistance during this time period. The US was motivated to assist the Hondurans in nation building and enhance the image of the US while expanding its sphere of influence and providing maximal training experience for its personnel [24]. Programs like MEDCAPs and MEDRETEs were often well recieved in Honduras because of the state of medicine there. Although there was an appearance of a local public health system, it had many shortcommings that stymied its success. These included staff shortages, with doctors gathered in large city centers, leaving isolated rural areas without medical care and severe budgetary constraints. Thus, the US military decided to assist Honduras with its medical care and infrastructure problems to ensure stabilization and promote development. HCA in Honduras was approached in a four tiered way: 1) hospital/clinics; 2) village outreach programs (transitory MEDRETEs); 3) contingency response; and 4) quarterly visits from maxillo-facial plastic surgery (Operation Smile-cleft lip and palate repair) [24].

The MEDRETEs were usually set up in a village 
school or church [25]. The majority of their patients were women and children, who are reported to have occasionally created fictionalized complaints simply for the opportunity to see a western doctor $[25,26]$. Other patients who were actually ill believed that the mere presence of a western physician could cure them [25].

These missions involved many types of medical interventions including primary care and preventive medicine, public health lectures delivered in Spanish, dentistry, surgery and even deworming [25]. Operation Smile is often hailed as an enormous success due to the visual impact of repairing a child's cleft and lip palate [27]. A team of plastic surgeons from William Beaumont Army Medical Center in El Paso TX would travel to Honduras four times a year and select patients for this surgery from predetermined villages [27]. Much like in Vietnam, the location of MEDRETEs was determined by the US military MEDRETE coordinator in consultation with Honduran military and local civilian officials based on a "particular need" [25]. Specific patient populations were also chosen by US and Honduran military, civilian and government officials, leading some physicians to express discontent at the limitations being placed on them in the clinical setting [25]. Rarely did MEDRETE teams revisit the same village.

Many military physicians who had participated in MEDRETEs expressed critiques of these programs. One point of discontent was the constraints placed on medical care by political and strategic requirements and necessity. These critiques often focused on the constraints and limitations placed on them by both the US military and the host nation government. Often the ability of a MEDRETE team to return to a specific village was dictated by the host nation government [28]. Thus, a physician or planner could not choose to return to a specific village to maintain continuity of care; these decisions were dictated by those higher up the chain of command in conversation with the host nation themselves. One participant expressed the concern that he felt that they were making villagers dependent on American military medical care by introducing these people to western medicine, and then never returning to provide follow up care [29]. This presented him with a type of moral dilemma, identifying chronic conditions for which he could do nothing. Other constraints included the fact that the host nation often dictated the patient population that could be seen, the villages that could be visited, as well as what services could be provided and what medications could be distributed [30].

Other constraints dealt with context and environment. These included the lack of support services, language barriers and being unfamiliar with the local culture, endemic diseases, the local health-care system, and standards of care [31]. There were also a large number of patients to see in a short amount of time. Often patients travelled from neighbouring villages for the opportunity to see an American physician [32]. The short-term and temporary nature of MEDRETEs were also a source of constant critique and discontent for the military physician. Often called "parachute medicine" training operations because teams dropped in and provided care for a short time and then left, this short-term model prevented long-term and follow up care for patients with chronic conditions [33]. Many participants recognized the need for long-term projects, and re-occurring MEDRETEs [34].

Discontent was not limited to the physician participants. The host nation governments were also critical of the benefit of early MEDRETEs [35]. The Ministry of Health in Honduras, as well as the Honduran College of Medicine, questioned the utility of the MEDRETEs [35]. Even Army South Command or SOUTHCOM recognized the shortcomings of the MEDRETE program. In a SOUTHCOM memorandum they stated,

We have done a good job winning the minds and heart of our hemisphere neighbors using these training vehicles. However, despite these efforts we are not able to demonstrate that we have actually done anything to improve the health of those we have treated in the past. The mere provision of a few medicines on a periodic basis can generate a great number of patients seen during a particular visit, but says nothing about the impact of our effort on the health of the population [35].

The medical practitioners provide the care then repeat these same critiques. The majority of participants interviewed expressed beliefs that the medical impact of MEDRETEs was minimal [29,32,36]. One participant thought that medically the MEDRETE was, "a disservice to the local population" [29]. This same participant was in Honduras from 1999-2000 and explained that prevailing physician sentiment was, "MEDRETEs would be a disservice to the local population and there was a lot of truth to that" [29]. Another participant referred to MEDRETEs as "band-aid medicine" [32]. The concept of "band-aid" medicine refers to the idea that little is done for the patients beyond putting on band aids and doling out multi-vitamins. For these reasons one physician described MEDRETEs as having, "no impact at all on a medical basis" [36].

\subsection{Positive Provider Experiences}

However, not all shared these critiques. Many providers felt that the medical care that was provided was of benefit to the MEDRETE patients. These perceived benefits on the part of the participants mark a drastic departure 
from the Vietnam MEDCAP. Clearly, the MEDRETE is not a "mirror-image" of the Vietnam-style MEDCAP. One author stated, "The hospital, and the MEDRETES, may not have contributed to the long-term development of a health service, but it made a long-term difference to the patients" [28]. Another military physician who had the opportunity to participate in both a MEDCAP and a MEDRETE explained that the medical value of the latter was far superior to the former [37]. This opinion was reiterated in the literature as many were beginning to realize that the traditional MEDCAP could be counterproductive and fail in its goal of creating confidence in the local host nation government due to lack of coordination and subpar medical care [38].

There were specific medical procedures and aspects of medical care that physicians recognized as useful in the MEDRETE setting. Internal medicine physicians were quick to note their limitations in this context. As one participant noted, "internal medicine is the management of chronic disease, there is not much internal medicine can do in a one day clinic at a MEDRETE” [39]. However, internists did discover the value of draining and injecting arthritic joints [36,39]. Surgeons were found to be extremely valuable for cleft lip and palate repairs, amputations, and draining abscesses [36]. Pediatricians felt great satisfaction and saw huge impact with deworming campaigns, and dentists had a significant impact on oral health by way of tooth extraction $[36,49]$. Optometrists have also had considerable success distributing perscription glasses. Although medicine was limited in the field, physicians were able to find avenues by which to make a therapeutic difference. Many MEDRETE participants found their experience rewarding, remembering these benefits and the appreciation of the patients [29,32,36, 39].

\section{A CALL REFORM}

Although there were many benefits to the MEDRETE and some participants had positive experiences, others still called for increased reform of civilian medical assistance programs. Physician participants and commentators were beginning to call for programs that, unlike the traditional MEDCAP, prioritized medical goals and sustained long-term benefits [38]. Other commentators called for more drastic reform of medical civilian assistance. Regina Gaillard is critical of the historical link between civic action and counterinsurgency, as well as low intensity conflict [40]. She argues that the linkage of a strategic and humanitarian mission has tainted the idealist qualities of the concept causing these programs to be counterproductive in achieving the US military's goals.

Gaillard argues that a reorientation effort should attempt to delink civic action programs and humanitarian and civic assistance activities from counterinsurgency and low intensity conflict (LIC) [40]. Gaillard was essentially calling for a prioritization of medical goals over military goals. Contemporary programs show that Gaillard's desired delinking of civic action and counterinsurgency of LIC has not been accomplished. Physician experience tells that MEDCAPs in Afghanistan and Iraq are aligned with the PSYOPs goals of counterinsurgency and LIC [41]. Cramblet has similar critiques and calls for a necessary distinction between war and low-intensity conflict. Programs developed during times of conflict, such as MEDCAPs, cannot simply be transplanted into peacetime or low-intensity conflict operations [42]. Cramblet also highlights noteworthy aspects of a successful MEDRETE such as sustainability, which includes the successful hand off of programs to locals and simplicity necessary for program continuation in developing nations [43].

\section{MILITARY DOCTRINE}

A significant issue for the MEDRETE program, which had also plagued the MEDCAP missions that preceded them, was a lack of military doctrine that specifically instructed participants in how to act in these environments. This lack of military doctrine was recognized by many commentators [11,44]. As Gonzalez wrote, "At present and in the past, even though medicine has been extensively used, there has never been a doctrine for its proper utilization in Latin America” [45]. The lack of doctrine on the topic is problematic because of the foundational role that it plays within the military institution. Military doctrine is essential in shaping the behaviour of soldiers and dictating their proper conduct. Thus, a lack of doctrine leaves participants in these programs without guidance.

These types of missions are authorized under Title 10, US Code. Section 401. Programs established under this statute are intended as opportunities for training. A secondary goal is non-threatening engagement with a foreign nation. It is crucial to note that humanitarian goals are not mentioned. Medical care is not the purpose of these programs; the main purpose is training, while medical care is specifically ancillary. In a way this serves to distinguish medical civilian assistance programs from other military, as well as non-military humanitarian programs. Funding has continued for these programs that are specifically earmarked for military training, rather than humanitarian assistance, stabilization, or foreign development. The clear emphasis placed on training can be understood a number of ways. Firstly, it can be understood as protecting the program and rationalizing it within the military budget, allowing physicians to provide at least some care to patients in need. In fact, many physicians believe in the care that MEDRETEs provide, 
and find it rewarding as both a training and humanitarian mission. Another way to understand the prioritization of training is that the military is being honest about its intentions. As opposed to the Vietnam-era MEDCAPs, which sometimes in- volved dishonesty and deception, this program presents itself as a training operation with ancillary benefit to host-nation patients.

FM 27-5 addressed public health, sanitation and preventive medicine initiatives but did not address direct patient contact programs such as MEDCAPs or MEDRETEs [46]. FM100-20-, "Military Operations in Low Intensity Conflict”, provides vague and uninstructive information regarding these missions, with no mention of the medical mission. At this time, LIC was a catchall term with little distinct doctrine [47]. Joint Publication 3-07.6, "Doctrine for Military Operations Other Than War” (MOOTW), provides additional guidance, stating that the first priority of military medicine is to US troops. However, "when planning for MOOTW, the potential to treat HN [host nation] population of allied military personnel must be considered" [48]. Authorized care to foreign civilians should be within resource limitations and should urge continued coordination between the medical and intelligence elements [48]. In fact, this publication recognizes medical operations in MOOTW as a "valuable intelligence source" [48]. Joint Publication 4-02, Doctrine for Health Service Support in Joint Operations, reiterates that no operation should supplant or compete with the existing local medical infrastructure [49]. This piece of doctrine recognizes the necessity of not creating redundant healthcare systems that simply duplicate local services. History has shown that competing or duplicating local services undermine the local economy, create hostile relations with the local medical community and thus they can be a disservice to the healthcare of the local community and the mission.

Taken together these doctrines provide little in the way of helpful guidance for military physicians participating in these missions, however, the doctrine does clearly establish these missions as being of strategic intent: aimed at training and engagement. In this way, the doctrine clearly established a political mission for these humanitarian programs. Thus, the doctrine is straightforward in its use of medicine as a "non-lethal weapon" or tool, employed toward military ends. However, beyond the basic programmatic intent and goals of medical civilian assistance, this doctrine provides little guidance for soldiers engaged in this work.

\section{Medical Rules of Engagement-“Life Limb or Eyesight”}

Aside from military directives and instructions, there are other rules that could inform, and thus help to shape, the conduct of officers while on medical civilian assistance missions. Many of the participants who shared oral histories identified the medical rules of engagement as the way by which they often balance their twin roles as a physician and a soldier [30,50,51]. These rules of engagement represent another form of military doctrine that provides guidance and informs the actions as well as the medical and strategic decision-making of the military physician.

Medical Rules of Engagement (MROE) are used to outline the current military restrictions on whom physicians can and cannot treat, for strategic reasons [52]. The name draws an analogy with the military "Rules of Engagement" (ROE) that determine the limitations and dictate the appropriate situations when a soldier can respond with his or her weapon. The restrictions are dictated by command for strategic and political purposes. Similarly, medical rules of engagement are meant to determine when and how medical personnel can respond with their medical skills and technology. For instance, while the Geneva conventions require the treatment of enemy combatant personnel, foreign civilian populations are not always treated within the combat zone due to scarcity of resources or security concerns. That being said, injuries concerning "life, limb or eyesight" are understood to be a deciding and over-riding factor [50]. If a patient presents with an injury that threatens their life, limb or vision, physicians are allowed to treat them, regardless of other factors. Unfortunately, although physicians use MROE as their litmus test for providing civilian care, "life, limb or eyesight" does not make treatment mandatory or expected. Tensions are still reported between physicians and commanding officers over whether or not to treat injured and diseased civilians presenting during times of hostilities and scare resources [50].

Medical rules of engagement provide another example, and more substantive evidence, to the life of the military physician as simultaneously existing in two professional roles: the soldier-with rules of engagement and the doctor-with patient obligations. The balance necessary for this kind of medical assistance mission is exemplified in the concept of "integration" drawn from doctrine and put forth by LtCOL Peter Cramblet in his US Army War College paper entitled, "US Medical Imperatives for Low Intensity Conflict". Drawing on experiences in Honduras, LtCOL Cramblet holds that

Medical commanders must understand the first principal of war, objective, and integrate their efforts with other elements of national power to ensure accomplishment... well meaning commanders with sometimes bored, medical staff assume implied medical missions which do not always support LIC objectives [53].

Cramblet highlights that the balance expected of mili- 
tary physicians is understood by the military to prioritize the mission. Institutional messages are mixed when they are treated like physicians, asked to practice medicine and yet expected to fulfill obligations to their role as a soldier. They are expected to do more than just doctor, and this balance can be delicate to maintain. However, the blame should not fall solely on the shoulders of the physician. Cramblet blamed a lack of clear mission statements in LIC environments. The themes of ambiguous mission statements, lack of doctrine and unclear directives are prevalent throughout the history of these programs.

Beyond the lack of doctrine, participants in these programs also receive little or no training prior to their involvement. A recent study showed that a quarter of the polled participants received no training for their humanitarian assistance missions [54]. Of those that received training, it was primarily on the job and in the field training. There was no formal, pre-deployment training [54]. This lack of training was found to have a negative impact on the effectiveness of the mission [54]. It also may explain why physicians are unaware of the strategic goals of these missions, expecting them to be solely humanitarian missions without strategic intent.

In looking at primary source materials, the goals may seem apparent. However, many oral histories confirm that those involved in these programs were not always aware of the strategic aim of these programs. The ambiguous nature of the programmatic goals, and their lack of dissemination made it difficult for physicians to understand and achieve success. While command sought strategic achievement, physicians aimed for medical and humanitarian triumph. The two goals had different and sometimes conflicting methods and end-points [55]. According to Robert Wilensky, the MEDCAP program was based upon both the "altruistic inclinations of their participants and the political aims of the US government" [56]. The distinction between the aims and inclinations of those people with "boots on the ground" and those developing the policy resulted in unmet expectations, confusion over roles and responsibilities, successes, endpoints and inappropriate policy implementation. This uncertainty and confusion only caused more frustration for the military medical professional.

The strategic intent of the doctrine that dictates these programs is undeniable. That being said the participants' motivations for involvement were often remarkably different. Anecdotal evidence, oral histories and a recent study by the Center for Disaster and Humanitarian Assistance Medicine CDHAM have shown that physicians are motivated by altruism and actively seek out these programs. The study included all branches, active duty and reserves from various duty positions. It showed that nearly half of the physicians surveyed indicated that hu- manitarian missions were a factor in their decision to join the military [57]. These numbers allow us to understand the values of the physicians participating in medical civilian assistance missions, and understand how physician participants may differ from the command in reference to the goals of the program. These missions appeal to a humanitarian urge rather than a strategic one. Although many military physicians may also agree with larger military goals, this study highlights the crucial role that humanitarian and altruistic values play in shaping the identity and choices of the military physician. Regardless of their views on strategic goals, military physicians place a high value on the possibility of participating in humanitarian missions as part of their military duties. "Many applicants to the USUHS... expressed positive feelings about the potential to go overseas... humanitarian missions are one of the key factors that led them to apply to USUHS and to prefer a career as a military physician [58]." Their identity as military physicians is thusly shaped by this beneficent drive, to provide medical care in a capacity they thought civilian life could not offer. The significance for the Army is also apparent. These programs are a key contributing factor to physician career planning. These missions also play a vital role in retention and recruitment. The same CDHAM study showed that $60 \%$ of respondents reported that humanitarian assistance missions were influential in their decision to stay in the military [58]. Due to the importance of these programs to military providers, their experience within these missions deserves closer attention. The significance of humanitarian missions in physician decision-making provides insight into the morally complicated space of the historical medical civilian assistance model. Medical civilian assistance programs have historically been a well-intentioned, misdirected and frustrating experience for physicians. While they expected a humanitarian operation of beneficent medical care, they were faced with the reality of a military operation with secondary medical goals.

Physician-soldiers are not exempt from the horror and realities of war. While MEDCAPs and MEDRETEs do not involve the trauma of IEDs and mass casualties, one must not discount the psychological impact of providing care in dangerous places, and the disappointment, frustration and impotence felt providing care felt to be inadequate. Within the setting of the MEDCAP or MEDRETE, a physician is the agent of a program with goals that represent his twin-roles. Physicians of contemporary western medicine are used to the comforts of the hospital. They are accustomed to diagnostic tests, support staff, specialist consults, patient follow-up and well-stocked pharmacies. These missions challenge physicians. They are forced to see patients with chronic diseases that would be curable, or at least manageable, stateside but 
for which a MEDCAP or MEDRETE can do nothing. Instead, providers are confronted with the realities of these missions.

Although such activities collect large numbers of villagers, the procedure appears to confirm the peasant's belief in magic merely with the statement that Western magic is more powerful than local magic. Such a procedure may win an election, but in the long run it is truly dangerous and represents an inexcusable prostitution of medical facilities [59].

The feeling of provider impotence frustrates them as they dispense multi-vitamins, aspirin, ibuprofen or a few days' course of antibiotics. This frustration is palpable in the way providers joke with each other to alleviate the tension; as one participant shared, his team would often say "All we have done here today is maybe given a couple of people ulcers from taking too much ibuprofen" [41]. This type of frustration has led other participants to see this work to be, "of limited value medically, it is an outstanding tool for propaganda" [60]. CPT John Irving described one Medical Civic Action Program as a "military maneuver", rather than a humanitarian mission [60]. The moral complexity does not appear to lie with the use of medicine as a strategic tool. Rather, what lies at the heart of provider complaints is the prioritization of strategy above all else. This reality becomes apparent in the fact that when medical goals are emphasized, and medical good is achieved, physicians find these experiences rewarding and positive. However, when these military physicians are morally challenged by an order to provide medical care that they believe to be inadequate and they often feel conflicted. This problem is one of dual loyalty.

\section{ACKNOWLEDGEMENTS}

I would like to thank my academic mentors who have guided my research and writing on this project: Dr. Jason Glenn, Dr. Howard Brody, Laura Hermer, Dr. John Fraser and Dr. Sanders Marble. Their guidance made this work come to fruition. The Institute for the Medical Humanities and the Graduate School for Biomedical Sciences at the University of Texas Medical Branch also provided academic and research support throughout this project.

I also wish to extend my special gratitude to the physician-soldiers who shared their personal stories with me. These oral histories enriched my study of military medicine and provided valuable insight into a uniquely complicated profession. Lastly I would like to acknowledge the never-ending support of my family and my husband, who motivate me in all I do.

\section{REFERENCES}

[1] Stanley (2010) Number 6000.16 military health support for stability operations.
[2] Gillett, M.C. (1981) The army medical department, 17751818. Center for Military History, Washington DC.

[3] Taylor, J.F. (1984) Health care as an instrument of foreign policy (a proposed expanded role for the army medical department). Master's Thesis, US Army War College, Carlisle Barracks, 15-16.

[4] Standage, S. (1993) A role for the army medical specialist corps in nation assistance. Master's Thesis, US Army War College, Carlisle Barracks.

[5] González, J. (2000) Harvest of empire: A history of Latinos in America. Viking, New York.

[6] González, J. (2000) Harvest of empire: A history of Latinos in America. Viking, New York, 13.

[7] Taylor, J.F. (1984) Health care as an instrument of foreign policy (a proposed expanded role for the army medical department). Master's Thesis, US Army War College, Carlisle Barracks, 4.

[8] Cobian, A.R. (1996) The US army: A partner for development. Master's Thesis, US Army War College, Carlisle Barracks.

[9] Taylor, J.F. (1984) Health care as an instrument of foreign policy (a proposed exapnded role for the army medical department). Master's Thesis, US Army War College, Carlisle Barracks, 16.

[10] Natkins, I.L. (1989) The role of health services in support of the theatre campaign plan. Master's Thesis, US Army War College, Carlisle Barracks, 4.

[11] Gonzalez, L.C. (1988) United States Military medicine’s role in low-intensity conflict in Latin America. Master's Thesis, US Army War College, Carlisle Barracks, 12.

[12] Agency for Internal Development (1982) Congressional presentation, fiscal year. 430 .

[13] Jenkins, E. (1988) Medical civic action programs (medcaps) and medical readiness training exercises (medretes) as instruments of foreign policy. Master's Thesis, US Army War College, Carlisle Barracks.

[14] Jenkins, E. (1988) Medical civic action programs (medcaps) and medical readiness training exercises (medretes) as instruments of foreign policy. Master's Thesis, US Army War College, Carlisle Barracks, 17.

[15] Jenkins, E. (1988) Medical civic action programs (medcaps) and medical readiness training exercises (medretes) as instruments of foreign policy. Master's Thesis, US Army War College, Carlisle Barracks, 21.

[16] Jenkins, E. (1988) Medical civic action programs (medcaps) and medical readiness training exercises (medretes) as instruments of foreign policy. Master's Thesis, US Army War College, Carlisle Barracks, 27.

[17] JTF-B (2012) Medical readiness training exercises (medrete). Joint Task Force Bravo.

http://www.jtfb.southcom.mil/library/factsheets/factsheet. asp?id=10291

[18] Department of the Army (1985) Field manual No 41-10: Civil affairs operations. Department of the Army, Washington DC, 10-20.

[19] Department of Defense (2008) Instruction 2205.02: Humanitarian and civic assistance (Hca) activities. 
[20] Department of Defense (1995) Instruction 2205.3: Implementing procedures for the humanitarian and civic assistance (Hca) program.

[21] Aller, L.F. (1994) Letters to the editor: Medretes. Military Medicine, 159, A4.

[22] Hood, C.H. (1991) The United States army medical department in low-intensity conflict. Military Medicine, 156, 64-67.

[23] Jenkins, E. (1988) Medical civic action programs (medcaps) and medical readiness training exercises (medretes) as instruments of foreign policy. Master's Thesis, US Army War College, Carlisle Barracks, 7.

[24] Hood, C.H. (1991) Humanitarian civic action in honduras. Military Medicine, 156, 292-296.

[25] Wittich, A.C. (1989) The medical care system and medical readiness training exercises (medretes) in Honduras. Military Medicine, 154, 20-21.

[26] DeKoning, B.L. Soto Cano air force base, Honduras. Life on the Line.

[27] Claypool, R.G. (1989) Military medicine as an instrument of power: An overview and assessment. Master's Thesis, US Army War College, Carlisle Barracks, 16.

[28] Mitchell IV, C.H. (1991) The medic as an instrument of national policy or what in the world is the department of defense doing in medical humanitarian assistance? Master's Thesis, US Army War College, Carlisle Barracks.

[29] Eagan Chamberlin, S.M., Interviewed (2012) Participant 5, transcript.

[30] Eagan Chamberlin, S.M., Interviewed (2012) Participant 2, interview notes.

[31] Crutcher, J.M. and Beecham, H.J. (1995) Short-team medical field missions in developing countries: A practical approach. Military Medicine, 160, 339.

[32] Eagan Chamberlin, S.M., Interviewed (2012) Participant 6, transcript.

[33] Cramblet, P.B. (1991) US medical imperatives for low intensity conflict. Master's Thesis, US Army War College, Carlisle Barracks.

[34] Lesho, E.P., Jawad, N.K. and Hameed, H.M. (2011) Towards a better approach to medical humanitarian assistance in Iraq and future counterinsurgency operations. Military Medicine, 176, 1-3.

[35] Weisser, R.J. (1993) The Maturing of medretes. Military Medicine, 158, 573.

[36] Eagan Chamberlin, S.M., Interviewed (2013) Participant 9, transcript.

[37] Eagan Chamberlin, S.M., Interviewed (2012) Participant 3, transcript.

[38] Taylor, J.A. (1985) Military medicine’s expanding role in low-intensity conflict. US Army.

[39] Eagan Chamberlin, S.M., Interviewed (2013) Participant 10 , interview notes.

[40] Gaillard, R. (1990) Civic action versus counterinsurgency and low intensity conflict in Latin American: The case for delinkage. Master's Thesis, US Army War College, Carlisle Barracks.
[41] Eagan Chamberlin, S.M., Interviewed (2013) Participant 8, interview notes and transcript.

[42] Cramblet, P.B. (1991) US medical imperatives for low intensity conflict, 1

[43] Cramblet, P.B. (1991) US medical imperatives for low intensity conflict, 15-16.

[44] Taylor, J.F. (1984) Health care as an instrument of foreign policy (a proposed exapnded role for the army medical department). Master's Thesis, US Army War College, Carlisle Barracks.

[45] Gonzalez, W.E. (1988) United States military medicine’s role in low-intensity conflict in Latin America.

[46] War Department (1947) Field manual 27-5: United States army and navy manual of civil affairs military government. Washington DC.

[47] Department of the Army and the Air Force (1990) Field manual 100-20: Military operation in low intensity conflict. Washington DC.

[48] Department of Defense (1995) Joint doctrine for military operations other than war. Joint Chiefs of Staff, Washington DC.

[49] Department of Defense, Chiefs of Staff (1995) Joint publication 4-02: Doctrine for health services support in joint operations. Washington DC.

[50] Eagan Chamberlin, S.M., Interviewed (2012) Participant 4, transcript.

[51] Eagan Chamberlin, S.M., Interviewed (2013) Participant 7, transcript.

[52] Sadlon, G.L. (2000) Army medical department leaders in military operations other than war. Master's Thesis, U.S. Army War College, Carlisle Barracks.

[53] Cramblet, P.B. (1991) US medical imperatives for low intensity conflict. Master's Thesis, US Army War College, Carlisle Barracks.

[54] Driftmeyer, J.E., Llewellyn, C.H. and US Participants Perspectives on Military Medical Humanitarian Assistance, Eds. (2002) Special operations and low intensity conflict office of the assistance secretary of defence, measures of effectiveness. Center for Disaster and $\mathrm{Hu}-$ manitarian Assistance Medicine, Bethesda.

[55] Malsby III, R. (2008) Into which end does the thermometer go? Application of military medicine in counterinsurgency: Does direct patient care by American service members work? Master's Thesis, US Army Command and General Staff College, Fort Leavenworth.

[56] Wilensky, R.J. (2004) Military medicine to win hearts and minds: Aid to civilians in the Vietnam War. Texas Tech University Press, Lubbock, 3.

[57] Driftmeyer, J.E. and Llewellyn, C.H. (2002) Humanitarian service: Recruitment \& retention effects among uniformed services medical personnel. Measures of Effectiveness Center for Disaster and Humanitarian Assistance Medicine, Bethesda.

[58] Driftmeyer, J.E. and Llewellyn, C.H. (2002) Humanitarian service: Recruitment \& retention effects among uniformed services medical personnel. Measures of Effectiveness Center for Disaster and Humanitarian Assis- 
tance Medicine, Bethesda, 3.

[59] Malsby III, R. (2008) Into which end does the thermometer go? Application of military medicine in counterinsurgency: Does direct patient care by American service members work? Master's Thesis, US Army Command and General Staff College, Fort Leavenworth, 66-67.

[60] Wilensky, R.J. (2004) Military medicine to win hearts and minds: Aid to civilians in the Vietnam War. Texas Tech University Press, Lubbock, 86-87. 